\title{
War and Peace in the Sixteenth-Century Southwest: Objected-Oriented Approaches to Native-European Encounters and Trajectories
}

\author{
Clay Mathers
}

Although the Southwestern United States was the focus for the largest sixteenth-century entrada in North America, evidence for the indigenous use, modification, and consumption of early European objects in this region has been surprisingly modest. ${ }^{1}$ In reviewing the archaeological record of sixteenth-century Southwestern entradas there is a notable scarcity of early European artifacts in indigenous domestic, mortuary, and other contexts. While sixteenth-century European objects are present in the Southwest, they are linked predominantly with sites associated with Spaniards and their indigenous Mexican allies, rather than indigenous Americans. More striking is that although large assemblages of European contact period items are found where Spanish-led expeditions spent the most time and encountered the greatest indigenous resistance, these same areas present limited evidence that early European objects were utilized in any significant way by indigenous communities - as tools, for display, or for ceremonial purposes. Elsewhere in the Southwest, where more peaceful relations prevailed, early contacts did result in materials being exchanged and incorporated into indigenous contexts, though these objects seldom bear signs of purposeful modification. This discussion argues that the clash and entanglement of material culture and ideational systems at the earliest phase of contact in the Southwest cannot be understood

1 In this discussion the physical and behavioral distinctions between these three are as follows: "use": refers to the employment of objects and materials without the purposeful redesign of their physical form - e.g., edge wear on a knife or axe resulting from repeated episodes of cutting; "modification": denotes a deliberate alteration in the physical form of an object to affect an aesthetic, functional, and/or symbolic transformation that differs from the object's original form, purpose, and/or cultural significance - e.g., converting a ceramic fragment into a perforated pendant; and "consumption": refers to the definitive act of taking an object out of circulation - e.g., by 'disposal' in a burial, ceremonial deposit, or trash midden where the object is unlikely to be retrieved. 
without reference to the types of initial contacts between indigenous peoples and Europeans (antagonistic or peaceful), the frequency of contacts and the primary motivations behind them, as well as the political histories of different indigenous groups encountered by early entradas. One of the key questions here is why sustained indigenous contact with large Spanish-led expeditions, carrying plentiful supplies of European materials, did not result in large-scale indigenous use, modification, and consumption of European goods.

The chapter concludes by outlining specific episodes of war and peace, and material exchange, during the 1540-1542 entrada of Francisco Vázquez de Coronado. Although conflict and "conquista" campaigns characterized many early contacts between indigenous and European groups in New Spain, La Florida, and the interior Southeast, the transformation of objects, communities, and strategic policies in these areas was locally variable and changed dramatically by the close of the sixteenth century. Materials characteristic of these changes and variegated responses are found across the Southwest, but have seldom been explored for the insights they provide into broader anthropological themes such as resistance, exchange, and agency. While part of this study focuses on the contextual analysis of objects, its broader goal is to begin comparing cultural trajectories at an interregional scale, particularly the American Southwest and Southeast in the first century of New-Old World contact. Both areas transitioned from initial imperial strategies of resource acquisition and conflict, to policies of settlement and missionization by the end of the 160os, and a similar suite of European objects was available in both areas. Nevertheless, the manner in which these objects were employed, modified, and consumed by indigenous groups and Europeans varies significantly, and in ways that reveal important aspects of the earliest colonial encounters in North America.

\section{$2 \quad$ Macro-Regional Trajectories and Comparisons}

Before turning to objects and assemblages, it is important to understand some of the broader contexts and histories in which these materials were embedded. Cultural and physical landscapes along the southern margins of North America in the sixteenth century held very different geographic, demographic, economic, and geopolitical potentialities for both indigenous polities and the bourgeoning Spanish Empire. Although early Southeastern entradas focused on the littoral margins of La Florida and on the indigenous chiefdoms nearby, later expeditions targeted larger, more aggregated, and hierarchical Mississippian chiefdoms in the interior. Compared with the Trans-Mississippi 
West, the Southeast was more proximal to the trade routes linking Spain's prosperous colonial activities in the Americas to its operational home base in Iberia. Though less socially and politically stratified than state-level societies in Mexico and Peru, Mississippian groups did exhibit multi-tiered site hierarchies, well-defined social ranking, institutionalized disparities in resource access, and clear signs of local and regional tribute payments.

By contrast, indigenous communities in the sixteenth-century Southwest were more "nodal," with large uninhabited or thinly populated areas extending 50-100 miles between some primary settlement clusters - particularly in arid interfluvial areas. In addition, a large buffer zone of hostile sedentary and hunter-gatherer groups (known pejoratively by the Spaniards as "Chichimeca") populated large swaths of territory for many hundreds of miles between Spanish-occupied regions in central Mexico and autonomous Pueblo communities situated on New Spain's northern frontier. This barrier persisted until the early 159 os when a pan-regional megadrought ended, more benign Crown policies of gift exchange and resettlement of indigenous communities were introduced, and the nearly 50-year long Chichimec War was concluded (Powell 1967).

Throughout the sixteenth century, the American Southwest was extremely remote from primary centers of Spanish colonial activity in the Caribbean and the Valley of Mexico. Located on the northern edge of New Spain, it was largely landlocked, peripheral to many colonial trade routes, and of questionable economic value with respect to agricultural, ranching, craft production, trade, and mining activities. Compared with Spanish-led expeditions in the Southeast, Southwestern entradas were almost exclusively pedestrian affairs, involving little or no maritime travel, and often requiring overland journeys of 800-1000 miles before reaching their initial destinations. Within the Southwest, there were few signs of the vertically integrated regional and interregional polities seen in contemporary Southeastern communities. Equally difficult to discern in the sixteenth-century Southwest were the developed systems of tribute, warfare, social ranking, and wealth disparities akin to those found in many Mississippian and Peninsular Florida chiefdoms.

As a first step in assessing indigenous-European material encounters in the American Southeast and Southwest, it is important to emphasize the general similarity in materials and object types present in the archaeological record of both areas. A list of these early object and material types - dating largely to the early/mid-sixteenth century - is included in Table 14.1 (below). In it we 
TABLE 14.1 Typical non-perishable artifact types and raw materials used as trade goods in the early Southwestern and Southeastern entradas (ca. AD 1500-1599)

\begin{tabular}{llcc}
\hline Object type & Raw material & Southwest & Southeast \\
\hline Adzes & Ferrous & $\checkmark$ & $\checkmark$ \\
Awls & Ferrous & $\checkmark$ & $\checkmark$ \\
Axes & Ferrous & $\checkmark$ & $\checkmark$ \\
Chisels & Ferrous & $\checkmark$ & $\checkmark$ \\
Knives & Ferrous & $\checkmark$ & $\checkmark$ \\
Clarksdale Bells & Cupreous & $\checkmark$ & $\checkmark$ \\
Tubular Beads & Cupreous & & $\checkmark$ \\
Chevron-Faceted Beads & Glass & $\checkmark$ & $\checkmark$ \\
Nueva Cádiz Beads & Glass & $\checkmark$ & $\checkmark$ \\
Tumbled Blue Beads & Glass & & $\checkmark$ \\
& & & \\
\hline
\end{tabular}

can see that iron objects such as flat axes, chisels, knives, and awls, as well as copper bells, and distinctive forms of glass beads were items frequently mentioned as "trade goods" or "gifts" in expedition documents. These same items appear in archaeological contexts in the Southeast and Southwest associated with indigenous communities known to have been in contact with Spanish-led entradas.

Despite some morphometric differences between early Spanish-European objects documented currently in these regions, the overall similarities are striking and are clearly important in helping to distinguish early entradas and contacts (ca. AD 1500-1550), from later expeditions and encounters (ca. AD 1551-1600) in both regions (Blanton 2018; Little 2008; Smith 1987). As Mathers (2013) has argued, some of the major distinctions between these assemblages, pre- and post-1550, relate to a fundamental shift in Crown policy from "conquista" campaigns to missions and colonization.

Other important variables in evaluating early indigenous-European material trajectories in the Southeast and Southwest include:

- the incidence of indigenous-European encounters;

- the chronology of these contacts, and

- the types of the activities they represent (e.g., what types of ethnic groups/ social classes were involved? And in what spatial-behavioral contexts?)

1. Contact Frequency. One stark difference in the cultural trajectories of La Florida and the Southeastern interior on the one hand, and northern New Spain on the other, is the incidence of indigenous-European 
contacts. Documented encounters between indigenous communities and Europeans began in the Southeast in the second decade of the 1500s and continued with some regularity to the end of the century (Table 14.2). By contrast, the earliest documented indigenous-European contact in the Southwest is 26 years later, in 1539, when Esteban the Moor and his indigenous allies reached the Zuni village of Hawikku (Flint and Flint 2005, 59-64). Indigenous-European contacts in the Southeast are not only more frequent throughout the sixteenth century, they also represent efforts to establish colonies and missions earlier than in the Southwest (e.g., compare the 1526 colonization attempt by Vázquez de Ayllón in coastal Georgia (Hoffman 1994), to Oñate y Salazar's 1598 colonial efforts in northern New Mexico (Ellis 1989, 9-23), and the 1566 mission established at Santa Elena in Georgia by Menéndez de Áviles (Milanich 2006, 92-83), with the earliest Southwestern mission founded in 1598 by Oñate y Salazar in northern New Mexico (Barrett 2012, 36-37)). The relative lag in the Southwest with respect to both colonization and missionization, and the general dearth of Spanish expeditions in that area until the late 150os, contributed significantly to the modest volume of European objects known to indigenous communities throughout the sixteenth century. The low frequency of indigenous-European contact in the sixteenth-century Southwest was due in large measure to: (1) its peripheral geopolitical/

TABLE 14.2 Comparison of the Spanish/European presence in the US Southeast and Southwest during the sixteenth century (Based on the number of years with documented indigenous-European contact)

\begin{tabular}{lrr}
\hline Decade & SE & SW \\
\hline $1500-1509$ & & \\
$1510-1519$ & 5 & \\
$1520-1529$ & 4 & \\
$1530-1539$ & 1 & 1 \\
$1540-1549$ & 5 & 3 \\
$1550-1559$ & 1 & \\
$1560-1569$ & 11 & \\
$1570-1579$ & 12 & \\
$1580-1589$ & 10 & 3 \\
$1590-1599$ & 10 & 5 \\
Total No. of Years with Episodes of & 59 & 12 \\
Contact & & \\
& & \\
\hline
\end{tabular}


geographic position relative to other strategic assets; (2) the success of Chichimec groups in limiting Spanish activities north of Mexico City, (3) the general lack of large, aggregated villages with stored food reserves, and (4) the severe megadrought that dominated the region between the mid-1570s and mid-1590s (Van West et al. 2013, 88, 93).

2. Contact Chronologies. Given the major shift in emphasis of Spanish-led expeditions at approximately mid-century - transitioning from large, "conquista"-style military efforts to smaller, evangelical missions and settlement - some attention to the timing of indigenous-European encounters in the Southwest and Southeast is appropriate. As Mathers (2013) suggests, the disruptive effects, crippling costs, and unfavorable international visibility resulting from "conquista" campaigns and their associated encomienda rewards system, characterized the early sixteenth century. Indigenous uprisings were common in the Americas throughout the sixteenth century (Figure 14.1) and were expensive to remedy. The adverse, wide-ranging consequences of these conflicts encouraged the Spanish Crown into enacting new policies and legislation (notably the New Laws of 1542-1543), designed to reorient its New World priorities towards smaller, less overtly belligerent expeditions. In comparing the two regions, it is significant that only one "conquista"-style entrada is known

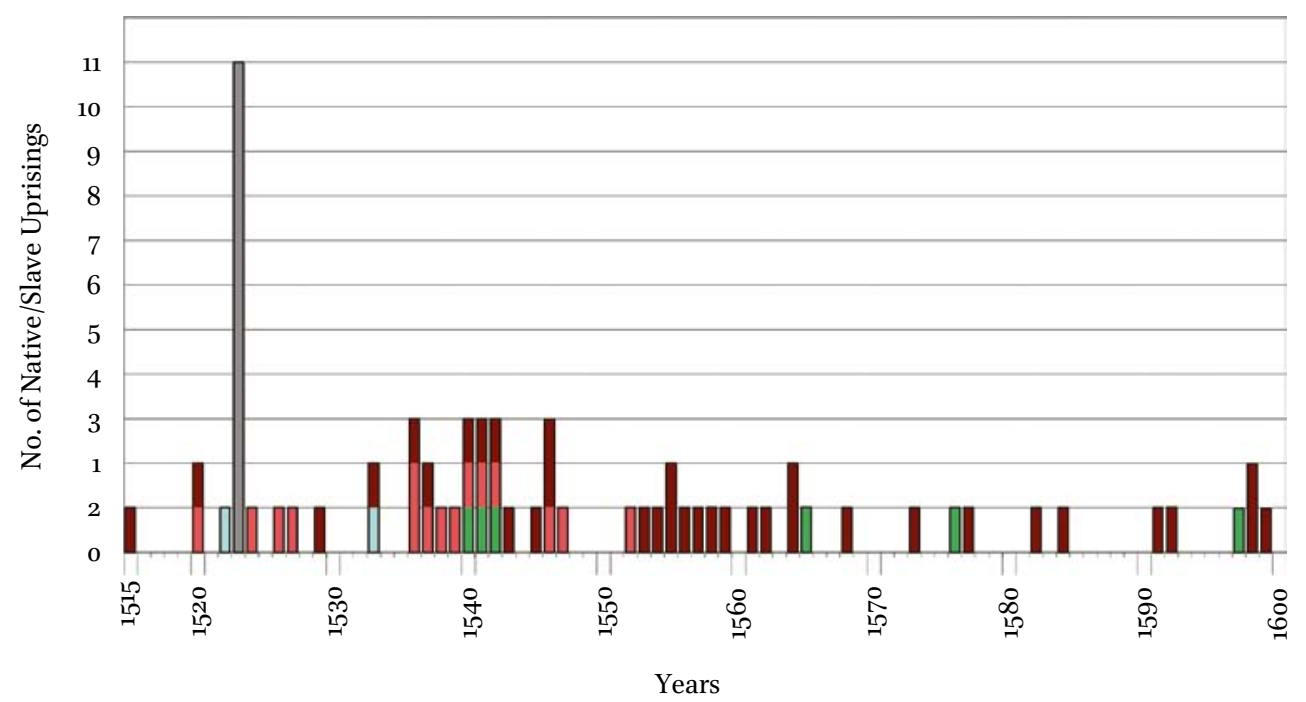

North America

Caribbean

Central America

South America

FIGURE 14.1 Frequency and chronology of selected sixteenth-century native and slaverelated uprisings in the Americas. The source of these data are a range of published archaeological and ethnohistorical literature from the Americas 
in the Southwest during the sixteenth century. Moreover, the number of years in which indigenous-European contact can be documented in the Southwest is only about a fifth of the contact years evidenced in the Southeast (Table 14.2). Encounters in the Southeast began earlier and were more frequent and varied than in the Southwest, involving a variety of terrestrial and maritime contacts, as well as an earlier shift from military-style expeditions to entradas involving a greater emphasis on settlement, gift exchange, and missionization.

3. Nature and Context of Contacts. In both the Southwest and Southeast, the character of sixteenth-century indigenous-European encounters varied from amiable and ephemeral, to protracted conflict and open warfare. Significantly perhaps, when terrestrial entradas remained for an extended period amongst indigenous communities in both areas the result was sustained conflict (e.g., Clayton et al. 1993a, 71-73; 1993b, 192-194; Mathers 2013). Smaller, more mobile maritime expeditions seldom faced such hostility, partly because they bulk transported their provisions, thereby reducing the pressures on local communities to supply them with food, shelter, and clothing. Entradas involving marine and riverine transport could often move rapidly from one indigenous area to another, with less effort, defend themselves more easily with large, well-armed water-borne vessels, and retreat more readily from danger, than their land-based counterparts.

Food shortages were the perpetual bane of sixteenth-century entradas and colonies from La Florida (Hudson 1997, 102-104, 167-171, 185-187, 378; Priestly 1928a, 139, 153, 203, 209; 1928b, 57) and Tierra Nueva (Flint and Flint 2005, 255-257, 291, 557-558) south to the Río de la Plata (Dominguez 2005, 9, 41, 107; García Loaeza and Garrett 2015, 6, 23, 56, 90) and Tierra del Fuego (Clissold 1954, 165-167). Provisioning large expeditions tended to strain indigenousEuropean relations the longer the latter made significant demands on the former. On the other hand, small expeditions were consistently in danger of attack and/or annihilation.

Smith and Hally (2019) have proposed that sixteenth-century European materials were obtained by indigenous Southeastern communities through mechanisms such as formal gift exchange, barter, battle trophies, theft/pilfering, scavenging, and shipwreck salvage. To this list, we could add transfers of European goods from indigenous guides and allies, who had obtained these items by various means, but often as a result of services rendered to European expeditionaries. The latter form of exchange is particularly significant since the "chaîne opératoire" for the transmission of European materials is made more complex in expeditions that included significant numbers of indigenous allies, 
such as the many Mexica and Tlaxcalans in Vázquez de Coronado's entrada in the Southwest (Flint 2009) and similar groups amongst Luna y Arellano's expedition in the Southeast (Bratten 2009, 109-110). While Spaniards engaged in early expeditions are known to have presented a variety of European-made goods to indigenous communities - especially as a means of establishing peaceful relations and strategic alliances (Flint 2002, 281-282; Hernández 2005, 110; Wilson 1990, 69) - conventional archaeological approaches have often seen such indigenous-European exchanges in rather simple linear terms - and with exchanges taking place primarily between elites (Figure 14.2). These simple models fail to account for indigenous allies as major actors in Spanish-led expeditions across the Americas and for their opportunities to participate actively in the exchange of European objects at a variety of social levels.

Because indigenous allies are mentioned infrequently in entrada-related narratives, examples of payments and rewards to indigenous expedition members are rare, and are generally restricted to higher social ranks. Examples include the right of the Tlaxcalan allies of Hernán Cortés to carry swords and

Model 1: Binary-Linear Transmission

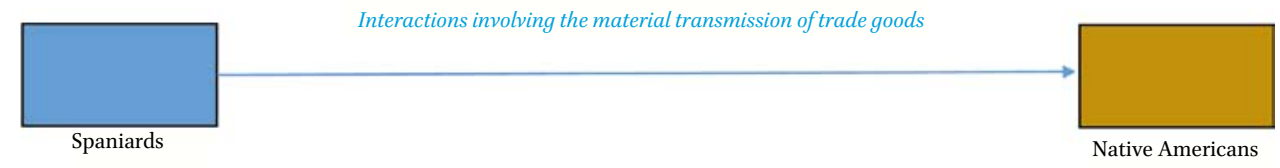

Model 2: Tripartite-Linear Transmission
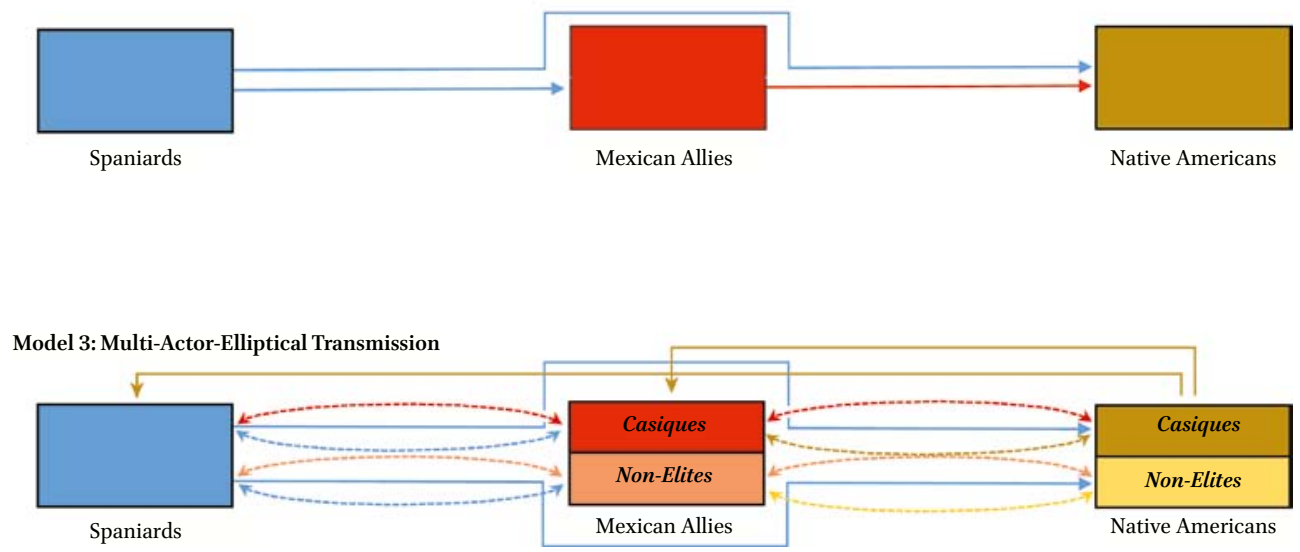

FIGURE 14.2 Schematic models of indigenous-European exchange in the American Southwest and Southeast 
firearms, wear Spanish clothing, and ride horses (Flint 2009, 75; Gibson 1968, 155), the gifts given by Marcos de Niza to discourage the desertion of his Mexican allies (Flint and Flint 2005, 74), and the "provisions for gratuitous distribution" offered by Adelantado Álvar Núñez Cabeza de Vaca to his indigenous Paraguayan allies (Hernández 2005, 173-174). It also appears that not all allies were regarded equally and that Spanish recruitment of indigenous auxiliaries often recognized a distinction between well-trained warriors (such as Nahau), and others (such as Tabascans), and apportioned expedition tasks accordingly (Chuchiak 2007, 199).

Having received or otherwise procured European objects, some allies may have created their own rules concerning when, what, and with whom they might trade, including both mundane and exotic European items. Accounts of indigenous auxiliaries starving and freezing to death on various expeditions, such Vázquez de Coronado's in the Southwest (Flint and Flint 2005, 235-236), or Diego de Almagro's on the Argentine-Chilean border (Pocock 1967, 26-27), suggest that the hardships associated with Spanish-led entradas could be extreme and have lethal consequences for many indigenous allies through combat, illness, exposure, poor diet, starvation, or some combination of these deprivations (e.g., Clayton et al. 1993a, 242; Flint 2009, 74; Francis 2007, 35; Restall and Asselbergs 2007, 16). Trading European objects for food in such resource-stressed or life-threatening situations may therefore have been commonplace - with respect to both indigenous allies and Europeans. Given the utilitarian nature of many of the sixteenth-century European objects that have emerged recently from the Stark Farm and Glass sites, in Mississippi and Georgia, respectively (Cobb and Legg 2017; Blanton 2019) - compared with traditional "gift items" such as beads and axes - we may be seeing material evidence of these more broadly-based trade relations between both indigenous and European non-elites. The complexities inherent in modeling indigenousEuropean exchange processes are compounded further in the Vázquez de Coronado entrada since after the expedition returned to Mexico City in 1542, a number of Mexican allies remained behind, choosing to live the remainder of their lives in indigenous communities such as the Zuni pueblo of Halona:wa (Hammond and Rey 1967, 89, 93).

With these complexities and challenges in mind, the following case studies focus on historically-, and/or archaeologically-, documented assemblages and objects, associated with the 1540-1542 entrada of Francisco Vázquez de Coronado. These four case studies highlight geographically discrete regions, ethnically distinct indigenous American communities, and generally follow the chronological trajectory of this expedition. 
Case 1: Hernando de Alarcón Naval Contingent, Sea of Cortes/ Lower Colorado River, (May-September(?) 1540)

Although designed as a supportive supply link for the terrestrial portion of this entrada, and perhaps some general reconnaissance, the naval segment of this expedition never fulfilled its primary mission owing to the scarcity of navigable waterways in the Desert Southwest. Departing from Acapulco, and then Culiacán, in what is now western Mexico, Alarcón's maritime expedition was well supplied with food, clothing, and weapons, as well as an unspecified number of crew. Once Alarcón reached the Colorado River, he was forced to continue using two small launches that could better navigate the swift, changeable currents.

Judging by Alarcón's report of his encounters with indigenous Yuma communities in the Lower Colorado River (LCR) Basin (Flint and Flint 2005, 185-205), his contacts were characterized by:

- Generally peaceful relationships, with no signs of conflict in the extant archaeological record or historical documents;

- Amicable gift giving - involving the presentation of European goods such as clothing, beads, and food;

- And as further evidence of peaceful relations, Alarcón reports numerous large wooden crosses being erected by Spanish expeditionaries, and their veneration by local Yuma communities.

Alarcón's generally benign contacts with indigenous communities in the LCR were largely the result of the expedition's:

1. Small Size: the relative symmetry between the size of the expedition and the indigenous communities they encountered;

2. Minimal Expedition Requirements: because of their relative selfsufficiency with regard to clothing, food, and shelter, the expedition made minimal demands on local communities;

3. Minimal Threats: the potential menace posed by Alarcón's entrada was negligible, owing to the expedition's modest size and requirements, minimal periods of occupation, and the relatively modest investment of Yuman communities in institutionalized social ranks (i.e., positions that could have been impacted adversely by the Spaniards, their alternative cultural values, and the dissent created by differential acquisition of exotic European objects);

4. Mutually Favorable Exchanges of Goods: Alarcón's plentiful supplies and the manner in which he distributed them, helped promote friendly relations with Yuman communities; 
To date there is no archaeological evidence from the LCR region to suggest how early trade items obtained from the Spaniards were used or consumed by indigenous communities.

Moving north from their initial departure point in western Mexico, and into what is now the border zone between New Mexico and Arizona, the Vázquez de Coronado expedition encountered a largely uninhabited area ("despoblado"), where provisions began to run dangerously low. Upon reaching the Zuni pueblo of Hawikku, Vázquez de Coronado was confronted by indigenous warriors and warned against entering their settlement. After a short engagement between Spaniards and their allies on the one hand, and Zuni warriors on the other, the former succeeded in defeating the Zunis and occupying Hawikku for the next four to five months. Shortly after the Battle of Hawikku, Vázquez de Coronado sought out the caciques from many Zuni pueblos to negotiate more peaceful relations. These contacts resulted in material exchanges between Spaniards and Zuni leaders that are confirmed in both sixteenth-century Spanish documents and in the archaeological record (Flint 2002, 281-282, Howell 2001; Mathers et al. 2011).

Since the size of the Vázquez de Coronado expedition at Zuni approached 3,000 individuals ( $\sim 75 \%$ consisting of indigenous Mexican auxiliaries), and more than 7,00o animals, local indigenous communities were faced with an immediate logistical and military dilemma of considerable magnitude. Unable to defeat the Spaniards and their allies in direct combat, Zuni communities opted for a more tactical plan of passive resistance and active reconnaissance to ensure that the Spaniards would soon look elsewhere for labor, clothing, food, and shelter. As part of this plan, Zuni guides spent months directing the Vázquez de Coronado expedition north to the Grand Canyon, west to the Hopi Pueblos, south to the Piro area, and east to the Buffalo Plains.

Our best archaeological evidence for encounters between the Vázquez de Coronado entrada and the Zuni come from the large-scale, 1917-1923 excavations at Hawikku (Smith et al. 1966) and Kechiba:wa (Hodge 1920; Lothrop 1923). Investigations at both pueblos recovered Vázquez de Coronado objects from residential and mortuary contexts, though excavators failed to recognize both their date and significance.

Analyses of Vázquez de Coronado objects from mortuary contexts at Kechiba:wa (Mathers et al. 2011) indicate that only $8.4 \%$ of the 266 excavated burials included European objects. All of these burials were adults; the individual's gender was not recorded. And while no comprehensive analyses have 
been undertaken of Vázquez de Coronado materials from Hawikku, Howell's research $(2001,151)$ on the 955 burials excavated there indicates only 13 included iron objects $(1.4 \%)$ and only $3(0.3 \%)$ contained copper artifacts; children and adults are more or less equally represented in these totals. Only seven Hawikku burials (0.73\%) contained European glass beads (Smith et al. 1966, 265), and only two excavated interments at Kechiba:wa contained Vázquez de Coronado-period glass beads - a nearly identical percentage $(0.75 \%)$. What is clear from these data is that known trade objects, dating to the Vázquez de Coronado entrada:

- Were directed towards a small percentage of adults and children at Zuni, indicating the presence of well-defined social ranks there (evidence of such hierarchical status and ranking is present at Zuni in both the prehistoric and early historic periods);

- These findings are congruent with Spanish narratives describing trade with Zuni caciques following the Battle of Hawikku;

- The exchange of European objects at Zuni emphasized items with a ceremonial, rather than utilitarian, value (e.g., small hatchet-like axes too thin and fragile to have been functional for cutting);

- European trade items at Zuni appear unmodified and are not visibly altered to conform to Zuni cultural aesthetics/norms.

The relatively peaceful relations between Zuni communities and the Vázquez de Coronado expedition, following their initial confrontation at Hawikku, is further demonstrated by the construction of large wooden crosses - documented by members of the Espejo entrada who noted these large, well-built crosses throughout the Zuni area in 1583 (Hammond and Rey 1967, 89).

Another significant object from the Hawikku excavations (National Museum of the American Indian Ref. No. 085899.000 (1)) is a small, reshaped ceramic fragment with Mexican painted motifs on its interior surface. This fragment has a small annular ring base on its exterior surface and was included as part of Hawikku Burial 899 - an infant accompanied by a small, finely woven basket/ tray, with this broken, decorated bowl fragment placed on its legs (Hodge 1918b, 140-141). The surviving decoration appears to represent a duck-like figure floating on water, with various additional symbols and glyphs along its margins. Discussions with a number of Mexican ceramic specialists in the us, Canada, and Mexico suggest that this fragment:

- Probably dates to the mid-late sixteenth century;

- Originates from Central Mexico - perhaps the Puebla-Tlaxcala region or more probably the Southern Basin of Mexico;

- Includes dot symbols (signifying numerals) and a "tepetl" (or place) glyph (Philip Arnold, Joseph Ball, Patricia Fournier, Geoffrey McCafferty, and Jeffrey Parsons, personal communications February 2017). 


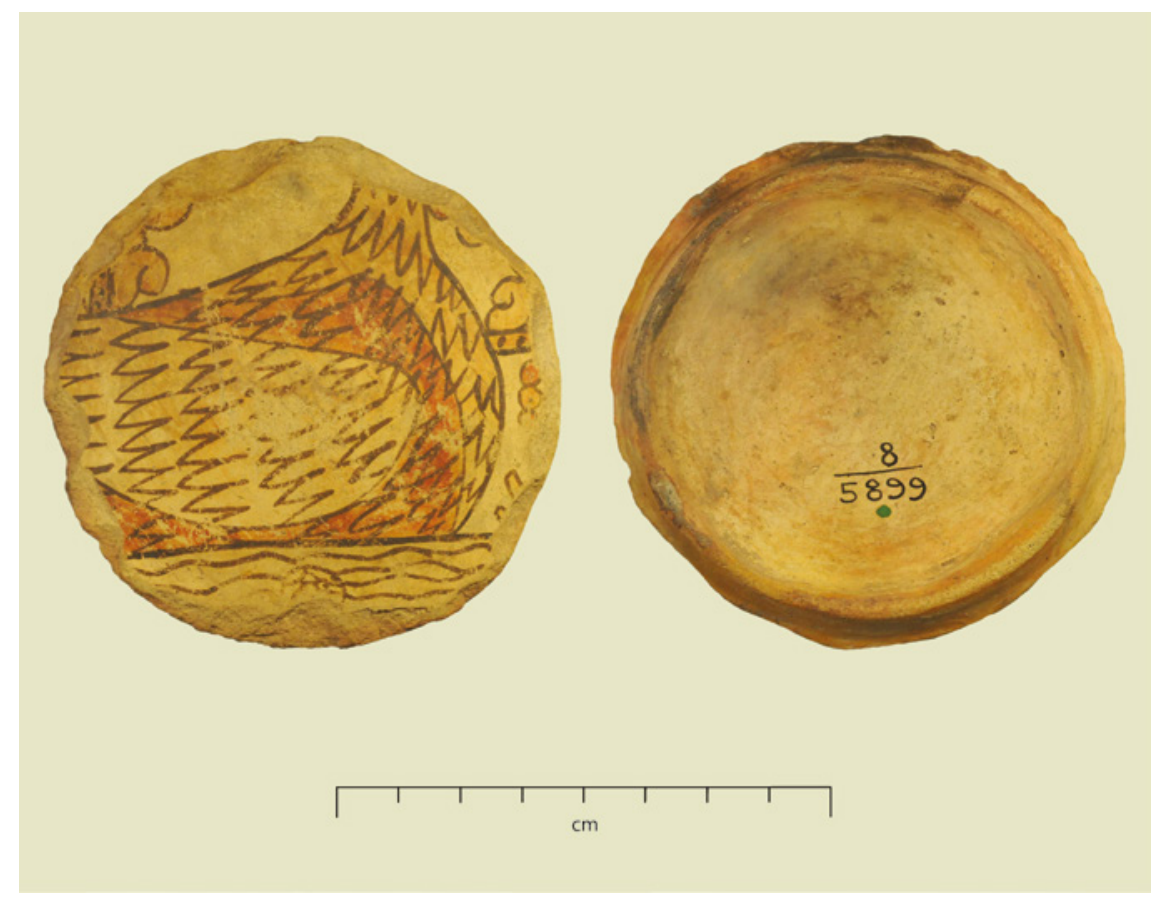

FIGURE 14.3 Shaped Mexican ceramic fragment with bird motif NATIONAL MUSEUM OF THE AMERICAN INDIAN (REF. NO. 085899.000 (1))

Patricia Fournier (personal communication, April 2012) suggested the design motif "might be part of early colonial period traditions that show drastic deterioration and oversimplified patterns, surface treatment, and colors of the Postclassic Cholula polychrome wares." In addition, the surface treatment of this sherd, its iconography, and annular base, are consistent with a mid- to late sixteenth-century Mexican chronology, possibly corresponding to Aztec IVstyle ceramic traditions (Griffin and Espejo 1950, Jeffrey Parsons personal communication, February 2017). Since the Vázquez de Coronado expedition spent four to five months encamped at Hawikku, with $\sim 2000$ Mexican auxiliaries, and at least three or four Mexican allies remained at Zuni after the expedition returned to Mexico City, the balance of evidence suggests this bowl is associated with the Vázquez de Coronado entrada.

The reshaping of this broken sherd appears to have been executed fairly carefully to produce a regularized edge that mirrors the annular base on its exterior surface. Significantly, a variety of other reshaped ceramic fragments appear at Hawikku $(n=16)$ - all of them found in mortuary contexts (Smith et al.1966, 237). These circular or rectilinear fragments are associated with both 
cremations and inhumations, and with adult, adolescent, and child burials. While the positioning of these sherds on the body was recorded in only three cases, one child burial had a single shaped sherd on its legs and another on its knee, in a manner similar to the placement of the shaped Mexican fragment from Burial 899. So, while there is evidence at Zuni for the reshaping of local ceramic fragments and incorporating them into burials, similar mortuary practices have not been documented to date in Central Mexico during the early historical period (Patricia Fournier personal communication, February 2017).

Whether the decorated Mexican fragment from Hawikku was associated with material left by Spaniards associated with the Vázquez de Coronado entrada, by Mexican allies during their 1540 occupation, or by indigenous auxiliaries remaining behind after the expedition returned to Mexico, it seems likely that this fragment:

- Constitutes one of the few material signatures of indigenous Mexicans known to date in the contact period Southwest;

- Was modified and then grafted into a set of existing Zuni mortuary practices that had previously been based largely, if not exclusively, on locally available indigenous American objects and materials; and

- Represents only a fraction of the extant indigenous Mexican material and behavioural repertoire from the contact period Southwest. Further evidence is suggested by a votive stone object from Hawikku Burial 59 with an appearance similar to the sword-like Mexica weapons known as "macanas" or "macuahuitls" and undecorated Mexican ceramic fragments - both found in the Western Cemetery (Hodge 1918a:376, fig. 8; 1918b, 371, 375).

\section{Case 3: Tiguex (Summer 1540-Spring 1542)}

Attempts by the Zuni to redirect Vázquez de Coronado to other areas of the Southwest, and to free themselves of this large occupying force, began bearing fruit in the autumn of 1540 . Having scouted widely in regions surrounding Zuni, Vázquez de Coronado and his commanders were convinced that the Tiguex region (now the metropolitan area surrounding Albuquerque, New Mexico) was the best place to establish themselves for the winter of 1540-1541. Bitterly cold conditions, the absence of clothing and other resources expected from Alarcón's supply ships, and the difficulty of provisioning such a large expedition, all conspired to create problems and animosity. Shortly afterwards, these tensions erupted into open hostility and sustained warfare. The Tiguex War lasted for more than a year and half, resulted in large numbers of casualties, and saw every Tiguex pueblo burned and damaged. 
Despite its scale and intensity, generations of scholars appear to have regarded this conflict as rather inconsequential, without either major or lasting consequences for the trajectory of indigenous-European relations in the Southwest. However, archaeological investigations are now providing evidence of the ferocity and consequences of the Tiguex War that have been missing from the rather limited perspective of Spanish documents (Mathers and Marshall 2014). These new analyses provide a fresh look at the material manifestations of combat, conflict, trade, and cultural transmission, and an opportunity to re-evaluate the Tiguex War using the rich detail of the archaeological record. A single European object from Santiago Pueblo, provides an example of these new perspectives.

At the time Santiago Pueblo was excavated, in 1934-1935, there was considerable enthusiasm to celebrate the 40oth anniversary of the Vázquez de Coronado entrada. Hoping to uncover material proof of this expedition in time for the 1940 anniversary, excavations were undertaken at Santiago, and at the nearby Pueblo of Kuaua. Ironically, materials uncovered at Santiago demonstrated exactly what the excavators hoped for, but nevertheless failed to recognize.

Diagnostic Vázquez de Coronado objects found during excavations at Santiago include copper crossbow quarrels, a caret-headed nail, and long copper lace chapes (Ellis 1957; Museum of Indian Arts and Culture n.d., Tichy 1939, 161-162). Despite their distinctive shape, size, form of manufacture, and widespread presence on European sites, in museums, and in the historical/ archaeological literature, crossbow quarrels at Santiago were regarded as possible "pen tips," as they had been in earlier investigations at Pecos Pueblo (Kidder 1932, 307, figure 251, i). Consequently, when a crossbow quarrel was found in the chest cavity of an indigenous burial at Santiago, it passed with little comment or analysis (Tichy 1939, 162).

Ellis (1957) was the first to identify crossbow quarrels in the American Southwest and specifically addressed his article to the examples found at Santiago Pueblo. In his pioneering paper, however, Ellis $(1957,213-214)$ suggested that crossbow quarrels could have been recovered and repurposed by indigenous communities for "re-use in Indian ways." Furthermore, Ellis $(1957,214)$ made specific reference to one crossbow quarrel-like object found in the Santiago excavations (Museum of Indian Arts and Culture, Catalog No. 44778/11, Bp 38/15). Ellis suggested it resembled the "tinklers" used by Pueblo and other Southwestern indigenous communities. The object described by Ellis is indeed a crossbow quarrel, though there is no evidence whatever to indicate that it was found in a context suggesting indigenous use, that there were modifications after it was distorted and broken following discharge, or that such objects had 
been modified and used by either Southern Tiwa communities or any other Pueblo/indigenous group in the Southwest.

Having predicted, and then discovered, a large Vázquez de Coronado battle assemblage in the vicinity of Santiago Pueblo (Mathers 2011, Mathers and Marshall 2014), questions arose about the function, and possible indigenous modification, of Vázquez de Coronado objects found in the 1930s excavations. In particular, whether crossbow quarrels were simply fired and unmodified or whether they were objects later repurposed by indigenous Pueblo communities into the form Ellis regarded as tinkler-like or ornamental.

Re-examination of the object Ellis suggested could be a crossbow quarrel transformed by indigenous groups into a tinkler-type ornament, suggests that: - This object is heavy, thick, and an unsuitable size and shape for producing any audible resonance;

- Furthermore, its wall thickness (1.4 $\mathrm{mm}$ ) would have made it difficult to reshape without a knowledge of annealing, and there are no tell-tale surface indications of the dimpling and impressions of stone tool working necessary to produce a more suitable tinkler-form;

- Instead, its maximum length, width, and thickness $(37.5 \mathrm{~mm}, 9.6 \mathrm{~mm}$, and $0.5 \mathrm{~mm}$ ) are all close to the mean and standard deviation (SD) of 18 nearly complete crossbow quarrels from Santiago with length and thickness measurements, and 11 crossbow quarrels with meaningful width measurements i.e., mean $=38.9 \mathrm{~mm}, 9.2 \mathrm{~mm}$, and $0.7 \mathrm{~mm}$, and $\mathrm{SD}=13.8 \mathrm{~mm}, 1.80 \mathrm{~mm}$, and $0.3 \mathrm{~mm}$ respectively.

Apart from the single burial at Santiago, neither crossbow quarrels nor metal tinklers of any kind are known from 394 excavated burials there, from the $\sim 600$ burials excavated at the Southern Tiwa Pueblo of Kuaua (Dutton 1963, 26), or the 42 and 23 burials with data from the Tiguex Pueblos of Alameda and Chamisal, respectively (Cordero 2013, 201-220). A similar absence of both object types is notable from 2000 excavated burials at the Towa Pueblo of Pecos, and from the Zuni Pueblos of Hawikku and Kechiba:wa with 955 and 266 excavated burials, respectively. All of these Southern Tiwa, Towa, and Zuni communities are known to have been contacted by the Vázquez de Coronado entrada, but none have produced burials with metal tinklers or crossbow quarrels.

Several salient patterns emerge from this analysis of Vázquez de Coronado materials in the Tiguex area:

- Despite the expedition's size and protracted occupation in this region, there are no clear signs that early European objects were used, modified, or consumed by Southern Tiwa communities - despite major excavations at six Tiguex sites (Cordero 2013; Dutton 1963; Marshall 1982; Pooler 1940; Sargeant 1985; Tichy 1939). 
- Early European objects found to date in and around Tiguex Pueblos appear to be the result of occupation, and/or attacks, by the Vázquez de Coronado entrada;

- Mortuary, ethnohistorical, and anthropological evidence from Tiguex suggests a history marked by little emphasis on the display of high value, exotic goods for marking rank and status (evidence of social 'leveling' or distributed authority, ranks, and status are marked features of Southern Tiwa mortuary practices throughout the prehistoric and early historic periods);

- Despite the unusual opportunities that Southern Tiwa groups had to acquire early European objects, very little evidence has emerged to suggest they did so;

- The overwhelming resource demands made by the Vázquez de Coronado expedition, and their arrival at the beginning of winter - when both indigenous communities and Europeans would be reliant on stored (indigenous) food supplies and clothing - created a lethal threat to indigenous communities that could not be finessed easily, as it was at Zuni;

- The antagonistic relationships between indigenous and European groups in Tiguex is underlined by only a single reference to the exchange of "a few small items" (involving Alvarado's initial encounter with Tiguex communities in 1540 (Flint and Flint 2005, 305)) and the lack of any clear evidence for the erection of crosses anywhere in Tiguex in all known historical narratives relating to this phase of the expedition.

\section{$7 \quad$ Case 4: Southern Plains (Spring-Summer 1541)}

Following their two-month siege of Moho, the expedition left Tiguex in the spring of AD 1541 in search of Quivira and major indigenous settlements in the Great Plains. Led by indigenous guides, they traveled east past Pecos Pueblo into the territory of Querecho and Teja groups in the Texas Panhandle, western Oklahoma, and Kansas (Habicht-Mauche 1992). Mobile buffalo hunters in these regions were represented by fairly small groups and mostly temporary settlements. Relations between the expedition and these indigenous communities appear to have been peaceful, despite the latter's reputation as fierce warriors (Flint and Flint 2005, 421, 423).

Notwithstanding the generally small, migratory nature of Querecho and Teja communities in the Southern Plains, and their often-ephemeral archaeological footprint, there are archaeological traces of European and Mexican objects from the Vázquez de Coronado entrada recorded in this region, as well as 
documentary evidence of wooden crosses being erected (Billeck 2009; Sudbury 1984; Bell 1959; Hoard et al. 2008, 223-225 and Flint and Flint 2005, 517, respectively). Artifacts include Nueva Cádiz and faceted chevron beads, a possible prismatic core of Mexican obsidian, and three examples of Pachuca obsidian.

It is likely that the overwhelming size and firepower of the Vázquez de Coronado expedition discouraged any hostile encounters with Querecho-Teja groups in the Southern Plains, and that the expedition's demands on these indigenous communities would have been minimal given the latter's modest size and resources. Objects linked with the Vázquez de Coronado expedition do not appear in any definitive contexts suggesting exchange targeted exclusively at indigenous Querecho-Teja leaders, so it is difficult, at this stage, to determine if such items were directed towards restricted social ranks. To date there is no sign that the original form of these objects was modified or reconfigured. And again, the erection of crosses and generally positive tone of expedition narratives for this area, suggests peaceful relations with the expedition throughout this region.

\section{Conclusion}

This chapter has emphasized the role of war and peace in influencing early encounters between indigenous and European communities in the American Southwest. It has also underlined a degree of congruence between the documentary and archaeological records on matters of indigenous-European material exchanges and relations. In addition, it has highlighted some of the major factors that impacted the trajectory of these exchanges and relations throughout the sixteenth century; the history and consequences of these interactions continued to resonate in the seventeenth century as well. A variety of geographic, climatic, historical, and geopolitical dynamics helped to maintain a relatively low level of indigenous-European contact in the Southwest, including its largely arid, landlocked landscapes; marginal productivity; peripheral position relative to other Crown assets; an historic mega-drought in the late 1500s; the paucity of large aggregated indigenous communities with significant stored food supplies; and a protracted, region-wide indigenous-European conflict lasting nearly fifty years.

Nevertheless, as the case studies above illustrate, the reaction of indigenous communities to encounters with Europeans in the sixteenth-century Southwest was far from uniform. Some groups - not overtaxed by demands for labor, food, and other resources - seem to have had reasonably amiable relations 
with Vázquez de Coronado and later entradas. And in those indigenous groups, like Zuni, where social ranking and material differentiation had some historical roots, European items obtained from Spanish-led expeditions were used to promote and sustain elevated socio-political and economic positions. Some key features of the more amiable indigenous-European encounters in the Southwest, appear to be:

- Limited exposure/European contact (involving relatively short expedition stays in the territories of any one indigenous community);

- Limited demands on indigenous resources; and

- Indigenous regions with limited to modest economic productivity (especially areas where stored food supplies and village sizes were restricted).

These conditions appear to have prevailed in the Lower Colorado River Valley, at Zuni (after some initial conflict), and in the Southern Plains. In Tiguex, however, conditions were badly aligned for any peaceful outcome - particularly with the arrival of the expedition at a time of year when the stored resources of Southern Tiwa communities were essential to their survival, and to the large occupying force of the Vázquez de Coronado expedition and their numerous livestock. Here local resources were insufficient to maintain both groups and their relations soon became lethal on a region-wide scale. The political histories of Southern Tiwa communities also played a key role in discouraging an interest in, as well as the acquisition and display of, exotic materials and objects.

Recent work in the Southeast to model entrada assemblages associated with Hernando de Soto (e.g., Blanton 2019; Mitchem 2014) have suggested that as this expedition moved inland and began to deplete its supplies and personnel, the resources available for distribution to indigenous communities began to diminish. While their resource reduction model is a new and important development in understanding early indigenous-European encounters, as well as the nature and trajectory of resource use through time, the Tiguex example above clearly suggests that the availability of "trade goods" (however defined) is only one element in a complex constellation of factors that need to be considered when attempting to understand issues of object use, modification, and consumption.

This discussion has attempted to consider many of the material exchange "vectors" involved in early indigenous-European relations and the assemblages of objects that resulted from them. One of the least tangible of these concern indigenous materials obtained by European expeditionaries - either from their indigenous allies (such as cotton-quilted armor and Mexica-indigenous weapons), or from indigenous American communities (such as blankets, ceramics, 
and food). Finding traces of these less visible items/exchanges remains a challenge for archaeologists addressing the early historical period. Nevertheless, the repurposed ceramic vessel from Hawikku, the Pachuca (Mexican) obsidian from the Vázquez de Coronado encampment near Santiago Pueblo in Tiguex (Vierra 1989, 119), the Mexica ceramics and obsidian from Luna y Arellano sites in the Pensacola area of Florida (Worth 2016), and the Coosawattee book/box plate from the Poarch Farm site in Georgia (Langford 1990), may point the way towards new possibilities and perspectives. Further material evidence of the Mexican presencein earlySpanish-led entradas mayhelp us uncover the breadth and depth of the multi-, rather than unidirectional, nature of indigenousEuropean exchanges and relations in the fifteenth and sixteenth centuries. In addition, it may help us understand the major organizational shift from Spanish-led expeditions that included indigenous allies recruited in Mexico (a sixteenth-century model) to indigenous American auxiliaries recruited locally (a practice more typical of the seventeenth century). Furthermore, as we recognize more of these objects, and the ethnic groups associated with them, we may begin to penetrate beneath the catch-all terminology of "indios amigos" and begin the more interesting analyses of the varied ethnic origins, roles, and cultural practices within different groups of indigenous allies during the first century of European contact.

Examples of indigenous Mexicans and Africans in the Southwest (Hammond and Rey 1967, 89; Flint and Flint 2005, 502), and Africans in the Southeast (e.g., Clayton et al. 1993b, 313), remaining behind when the expeditions they belonged to originally returned home, remind us that there are elements of the early historical period that remain silent and await thoughtful analysis. Zuni pueblos, for example, may have welcomed Mexica allies into their communities because of their military prowess and knowledge of Spanish customs and tactics, as Hopi villages were to incorporate Tano refugees for similar reasons following the First Pueblo Revolt in the late seventeenth century (Brooks 2016, $69-71,83,85$ ). Such cases remind us that, as we grapple with episodes of war and peace in the Early Americas, our understanding of indigenous-European material encounters - and the multifarious cultural dynamics that underlie them - becomes richer and more variegated. It is hoped that this modest effort to untangle a specific web of motivations, history, agencies, and processes will begin to encourage similar comparative efforts elsewhere - including approaches that are both regional and interregional. In doing so, we will continue the challenging task of connecting the objects of microhistory (and the "lived lives" of indigenous and European actors) to the broader patterns of macrohistory in historically meaningful ways. 


\section{Acknowledgments}

A number of colleagues were instrumental in providing support for the development of this chapter including: Rani Alexander, Philip Arnold, Joseph Ball, William Billeck, Tom Briones, Kathy Deagan, Tom Evans, Patricia Fournier, Jay Hart, Ron Kneebone, Alex Kurota, Shannon Mann, Michael Marshall, Geoffrey McCafferty, Peter McKenna, Jeffrey Mitchem, Patricia Nietfeld, Jeffrey Parsons, Helen Pollard, Dyane Sonier, Anthony Trujillo, and Tom Windes.

My profound thanks to Floris Keehnen, Corinne Hofman, Penelope Drooker, Robbie Ethridge, and Chris Rodning for their thoughtful comments on earlier versions of the manuscript.

A special thanks to the New Mexico Archaeological Council for their financial support in helping me to carry out work on the Hawikku/Kechiba:wa collections at the National Museum of the American Indian (NMAI), Suitland, MD.

\section{References}

Barrett, Elinore M. 2012. The Spanish Colonial Settlement Landscapes of New Mexico, 1598-1680. Albuquerque: University of New Mexico Press.

Bell, Robert E. 1959. "Obsidian Core Found in Western Oklahoma." El Palacio 66 (2): 72 .

Billeck, William. 2009. "Traces of Coronado: Spanish Glass Beads in the Southwest and the Plains." Poster presented at the 74th Annual Meeting of the Society for American Archaeology, Atlanta, 22-26 April.

Blanton, Dennis B. 2019. "Modeling Entrada-related Material Culture by Comparative Analysis of Sixteenth-Century Archaeological Assemblages from the Southeast." In The Destiny of Their Manifests: Modeling Sixteenth-Century Entradas in North America, edited by Clay Mathers. Gainesville: University Press of Florida.

Bratton, John. 2009. "Mesoamerican Component of the Emanuel Point Ships: Obsidian, Ceramics, and Projectile Points." The Florida Anthropologist $62(3 / 4)$ : 109-114.

Brooks, James F. 2016. Mesa of Sorrows: A History of the Awat'ovi Massacre. New York: W.W. Norton and Company.

Chuchiak, John F. Iv. 2007. "Forgotten Allies: The Origins and Roles of Native Mesoamerican Auxiliaries and Indios Conquistadores in the Conquest of Yucatan, 1526-1550." In Indian Conquistadors: Indigenous Allies in the Conquest of Mesoamerica, edited by Laura E. Matthew and Michel R. Oudijk, 175-225. Norman: University of Oklahoma Press. 
Clayton, Lawrence A., Vernon J. Knight, Jr., and Edward C. Moore (eds). 1993a. The De Soto Chronicles: The Expedition of Hernando de Soto to North America in 1539-1543 Volume 1. Tuscaloosa: University of Alabama Press.

Clayton, Lawrence A., Vernon J. Knight, Jr., and Edward C. Moore (eds). 1993b. The De Soto Chronicles: The Expedition of Hernando de Soto to North America in 1539-1543 Volume 2. Tuscaloosa: University of Alabama Press.

Clissold, Stephen. 1954. Conquistador: The Life of Don Pedro Sarmiento de Gamboa. London: Derek Verschoyle.

Cobb, Charles and Tony Legg. 2017. "Indigenous Appropriations of Spanish Metal Goods in Southeastern North America." Paper presented at the 82nd Annual Meeting of the Society for American Archaeology, Vancouver, 29 March-2 April.

Cordero, Robin M. 2013. Final Report on Excavations of the Alameda School Site (LA 421): A Classic Period Pueblo of the Tiguex Province. OCA/UNM Report no. 185-969. Office of Contract Archaeology. Albuquerque: University of New Mexico.

Dominguez, Luis L. (translator). 2005. The Conquest of the River Plate (1535-1555). I. Voyage of Ulrich Schmidt to the Rivers of La Plata and Paraguai from the Original German Edition, 1567. II. The Commentaries of Álvar Núñez Cabeza de Vaca from the Original Spanish Edition, 1555. Reprinted Elibron Classics, www.elibronclassics.com. Originally published in 1891 . London: Hakluyt Society.

Dutton, Bertha P. 1963. Sun Father's Way: The Kiva Murals of Kuaua, a Pueblo Ruin, Coronado State Monument, New Mexico. Santa Fe: Museum of New Mexico Press.

Ellis, Bruce T. 1957. "Crossbow Boltheads from Historic Pueblo Sites." El Palacio 64 (7/8): 209-214.

Ellis, Florence H. 1989. San Gabriel del Yungue as Seen by an Archaeologist. Santa Fe: Sunstone Press.

Flint, Richard. 2002. Great Cruelties Have Been Reported. The 1544 Investigation of the Coronado Expedition. Dallas: Southern Methodist University Press.

Flint, Richard. 2009. "Without Them, Nothing Was Possible: The Coronado Expedition's Indian Allies." New Mexico Historical Review 84 (1): 65-118.

Flint, Richard, and Shirley Cushing Flint, eds. and trans. 2005. Documents of the Coronado Expedition, 1539-1542. "They Were Not Familiar with His Majesty, nor Did They Wish to Be His Subjects." Dallas: Southern Methodist University Press.

Francis, J. Michael. 2007. Invading Columbia: Spanish Accounts of the Gonzalo Jiménez de Quesada Expedition of Conquest. University Park: Pennsylvania State University.

García Loaeza, Pablo and Victoria L. Garrett. 2015. The Improbable Conquest: Sixteenth-Century Letters from the Río de la Plata. University Park: Pennsylvania State University.

Gibson, Charles. 1968. The Aztecs Under Spanish Rule: A History of the Indians of the Valley of Mexico. Stanford: Stanford University Press. 
Griffin, James B., and Antonieta Espejo. 1950. "La alfaería correspondiente al último período de ocupación nahua del valle de México, II." Tlatelolco a través de los tiempos 11: 15-66.

Habicht-Mauche, Judith A. 1992. “Coronado's Querechos and Teyas in the Archaeological Record of the Texas Panhandle." Plains Anthropologist 140: 247-259.

Hammond, George P., and Agapito Rey, eds. and trans. 1967. Expedition into New Mexico Made by Antonio de Espejo 1582-1583 as Revealed in the Journal of Diego Pérez de Luxán, A Member of the Party. Reprinted Arno Press: New York. Originally published 1929, Quivira Society Publications, Volume I, Los Angeles: The Quivira Society.

Hernández, Pero. 2005. The Commentaries of Álvar Núnez Cabeza de Vaca from the Original Spanish Edition, 1555. Reprinted Elibron Classics, www.elibronclassics.com. Originally published 1891 . London: Hakluyt Society.

Hoard, Robert J., C. Tod Bevitt, and Janice McLean. 2008. "Source Determination of Obsidian from Kansas Archaeological Sites Using Compositional Analysis." Transactions of the Kansas Academy of Science 111 (3/4): 219-229.

Hodge, Frederick W. 1918a. "Excavations at the Zuni Pueblo of Hawikuh in 1917." Art and Archaeology 7 (9): 367-379.

Hodge, Frederick W. 1918b. "Hawikuh. III." Catalogue of Collections. Unpublished fieldwork notes. Carl A. Kroch Library, University of Microfilms, Ithaca.

Hodge, Frederick W. 1920. "The Age of the Zuni Pueblo of Kechipauan." Indian Notes and Monographs 3 (2): 41-60.

Hoffman, Paul E. 1994. "Lucas Vázquez de Ayllón's Discovery and Colony." In The Forgotten Centuries: Indians and Europeans in the American South, 1521-1704, edited by Charles Hudson and Carmen Chaves Tesser, 36-49. Athens: University of Georgia Press.

Howell, Todd. 2001. "Foundations of Political Power in Ancestral Zuni Society." In Ancient Burial Practices in the American Southwest: Archaeology, Physical Anthropology, and Native American Perspectives, edited by Douglas R. Mitchell and Judy L. Brunson-Hadley, 149-166. Albuquerque: University of New Mexico Press.

Hudson, Charles. 1997. Knights of Spain, Warriors of the Sun: Hernando de Soto and the South's Ancient Chiefdoms. Athens: University of Georgia.

Kidder, Alfred V. 1932. The Artifacts of Pecos. New Haven: Yale University Press.

Langford, James B. Jr. 1990. "The Coosawattee Plate: a Sixteenth-Century Catholic/ Aztec Artifact from Northwest Georgia." In Columbian Consequences, Vol. 2: Archaeological and Historical Perspectives on the Spanish Borderlands East, edited by David Hurst Thomas, 139-151. Washington, D.C.: Smithsonian Institution Press.

Little, Keith J. 2008. "European Artifact Chronology and Impacts of Spanish Contact in the Sixteenth-Century Coosa Valley." Unpublished PhD diss., Department of Anthropology, University of Alabama. 
Lothrop, Samuel K. 1923. "Ketchipauan - General Notes and Diary." Transcription by Keith Kintigh. Manuscript on file at the University Museum of Archaeology and Anthropology, University of Cambridge, England.

Marshall, Michael P. 1982. Excavations at Nuestra Señora de Dolores Pueblo (LA 6777), A Prehistoric Settlement in the Tiguex Province. Office of Contract Archaeology, Albuquerque: University of New Mexico.

Mathers, Clay. 2011. "Tangled Threads, Loose Ends, and Knotty Problems: The Place of Moho in Tiguex Archaeology, Geography, and History." In The Latest News from 1540. People, Places and Portrayals of the Coronado Expedition, edited by Richard Flint and Shirley Cushing Flint, 367-397. Albuquerque: University of New Mexico Press.

Mathers, Clay. 2013. "Conquest and Violence on the Northern Borderlands Frontier: Patterns of Native-European Conflict in the Sixteenth-Century Southwest." In $\mathrm{Na}$ tive and Spanish New Worlds: Sixteenth-Century Entradas in the American Southwest and Southeast, edited by Clay Mathers, Jeffrey M. Mitchem, and Charles M. Haecker, 225-255. Tucson: University of Arizona Press.

Mathers, Clay, and Michael P. Marshall. 2014. "Missing Links' and the War of the Worlds in Tiguex (1540-1542)." Paper presented at the 79th Annual Meeting of the Society for American Archaeology, Austin, TX, 23-27 April.

Mathers, Clay, Dan Simplicio, and Tom Kennedy. 2011. "Everywhere They Told Us He Had Been There': Evidence of the Vázquez de Coronado Entrada at the Ancestral Zuni Pueblo of Kechiba:wa, New Mexico." In The Latest Word from 1540: People, Places, and Portrayals of the Coronado Expedition, edited by Richard Flint and Shirley Cushing Flint, 262-285. Albuquerque: University of Mexico Press.

Milanich, Jerald T. 2006. Laboring in the Fields of the Lord: Spanish Missions and Southeastern Indians. Gainesville: University Press of Florida.

Mitchem, Jeffrey M. 2014. "Archaeological Evidence of the Hernando de Soto Expedition in the Southeastern United States." Lecture presented for the Archaeological Conservancy, Albuquerque, 17 September.

Museum of Indian Arts and Culture. n.d. Collections for Puaray or Santiago Pueblo (Laboratory of Anthropology Site Number 326). Object Catalog Numbers: 44778/11, Bp 38/15, Object Name: "Nails"; 49925/11a-c, Bp 38/5, Object Name: “Tinkler." Santa Fe, NM.

Pooler, Lolita M. 1940. “Alameda Pueblo Ruins.” El Palacio 47 (4): 84-89.

Powell, Phillip W. 1967. Mexico's Miguel Caldera: The Taming of America's First Frontier (1548-1597). Tucson: University of Arizona Press.

Priestley, Herbert Ingram, ed. and trans. 1928a. The Luna Papers, Documents Relating to the Expedition of Don Tristán de Luna y Arellano for the Conquest of Florida in 1559-1561. Volume 1. Deland: Florida State Historical Society.

Priestley, Herbert Ingram, ed. and trans. 1928b. The Luna Papers, Documents Relating to the Expedition of Don Tristán de Luna y Arellano for the Conquest of Florida in 1559-1561. Volume 2. Deland: Florida State Historical Society. 
Restall, Matthew, and Florine Asselbergs. 2007. Invading Guatemala: Spanish, Nahua, and Maya Accounts of the Conquest Wars. University Park: Pennsylvania State University.

Sargeant, Kathryn. 1985. An Archaeological and Historical Survey of the Village of Los Ranchos. Santa Fe: New Mexico Historic Preservation Division.

Smith, Marvin T. 1987. Archaeology of Aboriginal Culture Change in the Interior Southeast: Depopulation during the Early Historic Period. Gainesville: University Press of Florida.

Smith, Marvin T. and David J. Hally. 2019. "The Acquisition of Sixteenth-Century European Objects by Native Americans in the Southeastern United States." In The Destiny of Their Manifests: Modeling Sixteenth-Century Entradas in North America, edited by Clay Mathers. Gainesville: University Press of Florida.

Smith, Watson, Richard B. Woodbury, and Nathalie F.S. Woodbury. 1966. The Excavation of Hawikuh by Frederick Webb Hodge. Report of the Hendricks-Hodge Expedition 1917-1923. Contributions from the Museum of the American Indian, Heye Foundation, Volume 20. New York: Museum of the American Indian, Heye Foundation.

Sudbury, Byron. 1984. "A Sixteenth-Century Spanish Colonial Trade Bead from Western Oklahoma." Bulletin of the Oklahoma Anthropological Society 33:31-36.

Tichy, Marjorie. 1939. "The Archaeology of Puaray." El Palacio 46(7): 145-163.

Van West, Carla R., Thomas C. Windes, Frances Levine, Henri D. Grissino-Mayer, and Matthew W. Salzer. 2013. "The Role of Climate in Early Spanish-Native American Interactions in the U.S. Southwest." In Native and Spanish New Worlds: SixteenthCentury Entradas in the American Southwest and Southeast, edited by Clay Mathers, Jeffrey M. Mitchem, and Charles M. Haecker, 81-98. Tucson: University of Arizona Press.

Vierra, Bradley J. ed. 1989. "A Sixteenth-Century Spanish Campsite in the Tiguex Province." Laboratory of Anthropology Note 475. Santa Fe: Museum of New Mexico.

Worth, John E. 2016. "Interpreting Spanish Artifact Assemblages in the Mid-SixteenthCentury Southeast: The View from the 1559-1561 Tristán de Luna Settlement on Pensacola Bay." Paper presented at the 73rd Annual Meeting of the Southeastern Archaeological Conference, Athens, GA, 26-29 October.

Wilson, Samuel M. 1990. Hispaniola: Caribbean Chiefdoms in the Age of Columbus. Tuscaloosa: University of Alabama Press. 